\title{
Nutrient dynamics with application of humic substances and liming in irrigated soil filled columns
}

\section{Dinâmica de nutrientes com a aplicação de substâncias húmicas e calagem em colunas de solo irrigadas}

\author{
Cleire Luciano de Oliveira ${ }^{1}$; Rose Luiza Moraes Tavares ${ }^{2 *}$; Renato Lara de Assis ${ }^{3}$; \\ Veridiana Cardozo Gonçalves Cantão ${ }^{2}$; Cássio Sitta ${ }^{1}$
}

\section{Highlights}

In acidic soil, fulvic acid released $83 \%$ more $\mathrm{P}$ with application rate of $240 \mathrm{~L} \mathrm{ha}^{-1}$.

In acidic soil, fulvic acid released $40 \%$ more $P$ than humic acid.

In corrected soil, humic acid released $20 \%$ more $\mathrm{Mg}$ with application rate of $240 \mathrm{~L} \mathrm{ha}^{-1}$.

\begin{abstract}
The objective of this work was to evaluate the retention of $\mathrm{P}, \mathrm{K}, \mathrm{Ca}$ and $\mathrm{Mg}$ nutrients, as well as $\mathrm{pH}$ and electrical conductivity in Oxisols. Soil samples were placed into columns, with addition of humic substances (soil with and without liming). The experiment was conducted in a greenhouse and the columns consisted of PVC tubes with $40 \mathrm{~cm}$ height $\times 5 \mathrm{~cm}$ diameter. The humic substances used were humic acid and fulvic acid, applied at rates of 0,60, 120 and $240 \mathrm{~L} \mathrm{ha}^{-1}$, in soil with or without lime. Ten irrigation events were performed, simulating $32 \mathrm{~mm}$ rainfall. After that, samples were collected from the columns, at 0-20 and 20$40 \mathrm{~cm}$ depths, to identify the residual effect of the addition of humic substances. A completely randomized design was used for this experiment, with $2 \times 2 \times 4$ factorial statistical model and 3 replications. The results showed that, under acidic soil conditions, the use of fulvic acid provides more significant $P$ release (up to $40 \%)$ in soil when compared to humic acid. When the rate of $240 \mathrm{~L} \mathrm{ha}^{-1}$ is applied, the fulvic acid can release up to $83 \%$ of $\mathrm{P}$ in the soil.
\end{abstract}

Key words: Organic compounds. Nutrient availability. Tropical soils.

\section{Resumo}

Neste trabalho avaliou-se a retenção dos nutrientes $\mathrm{P}, \mathrm{K}, \mathrm{Ca}$ e $\mathrm{Mg}$, além do $\mathrm{pH}$ e condutividade elétrica em Latossolos, inseridos em colunas e adicionados de substâncias húmicas (na ausência e presença de calagem). $O$ experimento foi conduzido em casa de vegetação e as colunas foram compostas por colunas

1 Agronomic Engineer, M.e in Plant Production, University of Rio Verde, UniRV, Rio Verde, GO, Brazil. E-mail: cleiremin@ hotmail.com; cassiositta@hotmail.com

2 Profas Dras, School of Agronomy, UniRV, Rio Verde, GO, Brazil. E-mail: roseluiza@unirv.edu.br; veridiana@unirv.edu.br

3 Prof. Dr., School of Agronomy, Federal Institute of Education, Science and Technology Goiano, IF Goiano, Iporá, GO, Brazil. E-mail: relassis@bol.com.br

* Author for correspondence

Received: Oct. 13, 2020 - Approved: Feb. 04, 2021 
de PVC de $40 \mathrm{~cm}$ de altura e $5 \mathrm{~cm}$ de diâmetro. As substâncias húmicas utilizadas foram o ácido húmico e o ácido fúlvico aplicados nas doses 0, 60, 120 e $240 \mathrm{~L} \mathrm{ha}^{-1}$ em solo com ou sem calcário. Dez eventos de irrigação foram realizados simulando chuvas de $32 \mathrm{~mm}$. Em seguida, amostras das colunas foram coletadas nas profundidades de 0-20 e 20-40 cm para identificar o efeito residual da adição de substâncias húmicas. O experimento foi em delineamento inteiramente casualizado, com modelo estatístico fatorial $2 \times 2 \times 4 \mathrm{com}$ 3 repetições. Os resultados mostraram que em condições de solo ácido, o uso do ácido fúlvico é mais expressivo na liberação de $\mathrm{P}$ (até $40 \%$ de liberação) no solo quando comparado ao ácido húmico. $\mathrm{E}$, quando utilizada a taxa de $240 \mathrm{~L} \mathrm{ha}^{-1}$, o ácido fúlvico pode liberar até $83 \%$ de $\mathrm{P}$ no solo.

Palavras-chave: Compostos orgânicos. Nutrientes diponíveis. Solos tropicais.

\section{Introduction}

The humified soil organic matter (OM) plays an essential role in the functioning of tropical soils, characterized as acidic and infertile soils due to intense weathering. An example of such material in soil are the humic substances, composed of a fraction with higher reactivity in acidic and basic (alkaline) $\mathrm{pH}$ (fulvic acid) and a fraction of lower reactivity and soluble in alkaline media (humic acid), which can form complexes with organic compounds or metal ions (Baldotto \& Baldotto, 2014), thus providing benefits to the soil, such as reduction of nutrient leaching due to the presence of adsorption sites. Soil humic substances are condensed organic compounds produced by microbialactivity, which differ from biopolymers (proteins, carbohydrates, cellulose, etc.) due to their complex molecular structure and high persistence in soil (Rose et al., 2014).

However, the investigation regarding molecular structures of humic substances, in the current research scenario, is a quite difficult subject of study, not being possible to describe their molecular configurations so far, although the elemental composition and functional groups of those substances have been reasonably well characterized (Baldotto
\& Baldotto, 2014), that is, after chemical fractionation, the chemical composition of humic acid is $\mathrm{C}_{187} \mathrm{H}_{186} \mathrm{O}_{89} \mathrm{~N}_{9} \mathrm{~S}$ and of fulvic acid is $\mathrm{C}_{135} \mathrm{H}_{182} \mathrm{O}_{95} \mathrm{~N}_{5} \mathrm{~S}_{2}$ (Schnitzer \& Khan, 1972).

Fulvic acid, which contains more carboxyl groups per unit mass, presents total acidity higher than humic acid, with both organic acids having a proton charge per unit mass that is approximately two to three times larger than that typically observed for 2:1 silicate clay, which, in its turn, presents charge density approximately 100 times higher than the 1:1 clay, such as the kaolinite (Baldotto \& Baldotto, 2014). Since the soils in the Cerrado region are highly weathered, their clay fraction presents low charge and an appropriate CEC depends on the presence of soil organic matter (Souza \& Lobato, 2004).

Therefore, soil humic substances are important for charge generation in soils, especially those with low fertility. However, in the case of extremely acidic environment, such as Cerrado soils, the solubility of humic substances may be reduced, which interferes with the formation of metal-humic complexes (Melo, Motta, \& Santana, 2016). Usually, acid soil is associated with a reduction of nutrient availability (particularly phosphorus, calcium and magnesium) and an increase in the 
presence of acidic cations (hydrogen - $\mathrm{H}^{+}$, aluminum and iron) (Robson \& Abbott, 1989). Studies have revealed the potential for the use of soil humic substances, even under high acidity conditions. Karčauskienè et al. (2019) showed that the incorporation of humic acids helps regulate soil chemical status and neutralize its acidity. Yang, Zhang, Cong, Wang, and Shi (2013) identified an increment in $\mathrm{pH}$ and phosphorus availability upon addition of increasing rates of fulvic acid.

In view of the above, it is necessary to assess the effect of using humic substances in soil with and without liming, mainly in more weathered soils such as Oxisols, which are distributed over $39 \%$ of the Brazilian territory as the most representative class of soils in Brazil (Empresa Brasileira de Pesquisa Agropecuária [EMBRAPA], 2018).

The use of soil-filled columns to assess elements under imbalanced conditions (high acidity), with water applied in volume similar to natural precipitations, has been greatly employed as a technique for analysis of nutrient leaching in agricultural soils (Conte, Marques, Reis \& Viecelli, 2017). In this regard, aiming to identify the potential for the use of humic substances to increase crop production, the objective of this work was to assess the retention of the $\mathrm{K}, \mathrm{N}, \mathrm{Ca}$ and $\mathrm{Mg}$ nutrients in dystroferric Red Latosol, whose samples were placed into columns, with addition of fulvic or humic acid (soil with and without liming), after irrigation events under controlled moisture condition.

\section{Material and Methods}

The experiment was conducted at the University of Rio Verde - UniRV, in the municipality of Rio Verde, state of Goiás $\left(29^{\circ} 43^{\prime} 12^{\prime \prime} \mathrm{S}\right.$ and $\left.53^{\circ} 43^{\prime} 04^{\prime \prime} \mathrm{W}\right)$, in greenhouse with climate control system, by using a completely randomized design. According to the Koppen-Geiger classification system, the climate in Rio Verde is Aw type, typical of tropical climate and characterized by dry seasons from April to October, with average annual temperature of $23^{\circ} \mathrm{C}$ and average annual precipitation of $1550 \mathrm{~mm}$.

The treatments consisted in the use of two commercial humic substance-based products, one with larger quantity of humic acid $(\mathrm{HA})$ and the other with larger quantity of fulvic acid (FA) (Table 1), applied on soil with or without $\mathrm{pH}$ correction. The soil used in the experiment was Oxisols of medium texture, with $34 \%$ of clay, collected in area of native Cerrado vegetation at $0-20 \mathrm{~cm}$ depth, an its main chemical attributes are presented in Table 2. 
Table 1

Chemical analysis of commercial products containing humic and fulvic acids

\begin{tabular}{|cccc|}
\hline Variable & Unit & Humic Acid & Fulvic Acid \\
\hline Carbon - Humic Acid & $\%$ & 25.0 & 2.3 \\
\hline Carbon - Fulvic Acid & $\%$ & 5.0 & 26.0 \\
\hline Density & $\mathrm{g} \mathrm{mL}$ & 1.0 & 1.3 \\
\hline $\mathrm{pH}$ & - & 3.4 & 2.9 \\
\hline Organic Carbon & $\%$ & 31.0 & 18.0 \\
\hline Nitrogen & $\%$ & 3.2 & 1.5 \\
\hline Dry Mass & $\%$ & 2.4 & 1.3 \\
\hline Electrical Conductivity & $\mu \mathrm{cm}^{-1}$ & 7.3 & 6.5 \\
\hline
\end{tabular}

Table 2

Physical and chemical properties of Oxisol in area of native Cerrado vegetation in Rio Verde, Goiás

\begin{tabular}{|c|c|c|c|c|c|c|c|c|c|c|c|c|}
\hline Depth & $\mathrm{pH}$ & CEC & SB & K & $\mathrm{Ca}$ & $\mathrm{Mg}$ & V & $\mathrm{N}$ & $\mathrm{OM}$ & Sand & Silt & Clay \\
\hline $\mathrm{cm}$ & - & & 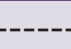 & $\mathrm{Ol}_{\mathrm{C}} \mathrm{d}$ & -2 & -- & $\%$ & & & $\mathrm{~kg}^{-}$ & & - \\
\hline $0-20$ & 4.2 & 7.1 & 0.2 & 0.0 & 0.1 & 0.04 & 3.4 & 0.03 & 15 & 400 & 260 & 340 \\
\hline
\end{tabular}

CEC: cations exchange capacity; SB: sum of bases; OM: organic matter.

After clods were broken, the soil samples were sieved through a $2 \mathrm{~mm}$ mesh sieve. Part of the soil samples had their $\mathrm{pH}$ corrected with calcitic lime with TRNP of $98 \%$, in the amount equivalent to $4 \mathrm{t} \mathrm{ha}^{-1}$ $\left(0.9 \mathrm{~g} \mathrm{column}^{-1}\right.$, with each column containing approximately $0.94 \mathrm{~kg}$ of soil). The base saturation method was applied for calculation of liming requirements, with a value of $60 \%$, which is ideal for development of crops like corn. The samples remained incubated for 30 days, with $70 \%$ of the water retention capacity, following the methodology by Conte et al. (2017).

The columns were built using PVC material, with $40 \mathrm{~cm}$ height $\times 5 \mathrm{~cm}$ diameter and both ends opened. At the bottom section of each column, textile filters (perflex material) were securely attached in order to retain the soil. After that, approximately $0.9 \mathrm{~kg}$ of soil was placed into the columns, being the quantity based on the natural density of $1.2 \mathrm{~g}$ $\mathrm{cm}^{-3}$ of the collected soil, which was assessed through undisturbed sample collection with the use of volumetric rings of known volume.

Humic substances were added to the treatments at the rates of $0,20,40$ and $80 \mu \mathrm{L}$ per column, equivalent to $0,60,120$ and $240 \mathrm{~L} \mathrm{ha}^{-1}$, based on the commercial recommendation for $60 \mathrm{~L} \mathrm{ha}^{-1}$ products and assessment of 2 and 4 times the recommended rate. Due to the small amount of organic acid per column, the products were applied in solution $(5 \mathrm{~mL}$ of solution per column), keeping the proportion of each dose. The main characteristics of humic substances are presented in Table 1. 
A total of 10 irrigation events were performed within a 30-day period and the column watering frequency was once every 3 to 4 days. The initial amount of water represented, under field conditions, $32 \mathrm{~mm}$ rainfall, which is ideal for the initial development of grain crops. The subsequent volumes of water added to the columns were monitored (weighed on scale), with the purpose to maintain the soil at field capacity, which was previously assessed through the Büchner funnel method (Costa, Nanni, \& Jeske, 1997). After completion of the irrigation events, soil samples were collected from the irrigation columns in the top (0-20 $\mathrm{cm})$ and bottom $(20-40 \mathrm{~cm})$ layers for analyses of soil macronutrients, according to EMBRAPA (2009), aiming to verify the residual effect of nutrients with addition of humic substances, after irrigation.

The experimental plots were arranged in a completely randomized design, with a $2 \times 2 \times 4$ factorial arrangement consisting of correction or not of soil acidity, 2 types of humic substances applied at 4 different rates, with 3 replications, totaling 48 sampling units.

Analysis of variance was conducted for data interpretation and, when the effect of variance sources was significant, Tukey's test was applied at $5 \%$ probability between the means. For effect of application rates, regression analysis was conducted (Ferreira, 2019).

\section{Results and Discussion}

Liming practice (factor 1) showed significant effect on the dynamics of $\mathrm{P}, \mathrm{Ca}$ and Mg nutrients, on $\mathrm{pH}$ and electrical conductivity in the $0-20 \mathrm{~cm}$ layer, as well as on $\mathrm{Ca}, \mathrm{Mg}$, $\mathrm{pH}$ and electrical conductivity in the 20-40 cm layer, after irrigations (Table 3). When the effect of using humic substances (factor 2) was assessed, with and without liming practice (factor 1), the results were significant for $\mathrm{Ca}$ in the $0-20 \mathrm{~cm}$ layer. In respect to the interaction of liming, humic substances and their application rates (factor 3 ), it was significant for $\mathrm{P}$ in the $0-20 \mathrm{~cm}$ layer, and for $\mathrm{P}, \mathrm{Mg}$ and electrical conductivity in the $20-40 \mathrm{~cm}$ layer (Table 3).

The liming practice produced significant increase in soil nutrient retention when compared to soil with no lime application (Table 4). That occurs because the increment of charges in soil, due to lime dissociation, generates anions (bicarbonate and hydroxide) that, though remaining shortly in soil since they quickly react with acids and disappear in the solution (Ernani, 2008; Souza \& Lobato, 2004), are capable of retaining cations, thus avoiding nutrient leaching. Therefore, in soil with the presence of lime, the $\mathrm{P}, \mathrm{Ca}$ and $\mathrm{Mg}$ contents were higher in the $0-20 \mathrm{~cm}$ layer, showing values of $0.5,5.2$ and $1.0 \mathrm{mg} \mathrm{kg}^{-1}$, respectively, when compared with soil without lime, where the values were $0.2,0.8$ and 0.2 $\mathrm{mg} \mathrm{kg}^{-1}$ (Table 2). The same tendency was observed for the $20-40 \mathrm{~cm}$ layer (Table 4). The generation of new charges in soil produces a rearrangement in the balance of cations between the solid and solution phases, favoring the displacement of pre-existing cations to the solid phase side and increasing the adsorption in colloids, with consequent higher retention of cations (Zandoná, Beutler, Burg, Barreto, \& Schmidt, 2015). 
Table 3

Summary of analysis of variance with Fc calculated for nutrients retained in the top $(0-20 \mathrm{~cm})$ and bottom $(20-40 \mathrm{~cm})$ layers of columns containing soil with or without $\mathrm{pH}$ correction

\begin{tabular}{|c|c|c|c|c|c|c|c|}
\hline Source of Variation & DF & $P$ & $\mathrm{~K}$ & $\mathrm{Ca}$ & $\mathrm{Mg}$ & $\mathrm{pH}$ & Cond \\
\hline & & \multicolumn{6}{|c|}{$(0-20 \mathrm{~cm})$} \\
\hline Liming & 1 & $32.97^{* *}$ & $1.33^{\mathrm{ns}}$ & $927.87^{* *}$ & $329.96 * *$ & $55.05^{* *}$ & $85.96^{* *}$ \\
\hline Humic substances-HS & 1 & $0.01^{\mathrm{ns}}$ & $0.24^{\mathrm{ns}}$ & $0.45^{\text {ns }}$ & $0.75^{\text {ns }}$ & $0.03^{\text {ns }}$ & $1.02^{\text {ns }}$ \\
\hline HS rate & 3 & $2.52^{\text {ns }}$ & $0.48^{\text {ns }}$ & $0.94^{\text {ns }}$ & $0.37^{n s}$ & $0.40^{\text {ns }}$ & $1.40^{\text {ns }}$ \\
\hline Liming $\times$ HS & 1 & $3.28^{\text {ns }}$ & $0.42^{\text {ns }}$ & $6.61^{*}$ & $7.36^{\text {ns }}$ & $2.27^{\text {ns }}$ & $5.48^{\text {ns }}$ \\
\hline Liming $\times$ HS rate & 3 & $4.53^{*}$ & $1.11^{\mathrm{ns}}$ & $1.25^{\mathrm{ns}}$ & $1.42^{\text {ns }}$ & $1.81^{\mathrm{ns}}$ & $1.10^{\text {ns }}$ \\
\hline $\mathrm{HS} \times \mathrm{HS}$ rate & 3 & $2.96^{*}$ & $0.30^{\text {ns }}$ & $1.66^{\mathrm{ns}}$ & $0.81^{\mathrm{ns}}$ & $0.49^{\text {ns }}$ & $0.80^{\text {ns }}$ \\
\hline Liming $\times \mathrm{HS} \times \mathrm{HS}$ rate & 3 & $3.36^{*}$ & $0.37^{\text {ns }}$ & $0.45^{\text {ns }}$ & $0.95^{\text {ns }}$ & $0.56^{\mathrm{ns}}$ & $0.85^{\text {ns }}$ \\
\hline Error & 32 & - & - & - & - & - & - \\
\hline \multirow[t]{2}{*}{ CV } & - & 43.75 & 28.03 & 16.65 & 24.12 & 24.53 & 36.77 \\
\hline & & \multicolumn{6}{|c|}{$(20-40 \mathrm{~cm})$} \\
\hline Liming & 1 & $0.04^{\text {ns }}$ & $2.12^{\text {ns }}$ & $1088.43^{* *}$ & $165.43^{* *}$ & $73.62^{* *}$ & $13.49^{* *}$ \\
\hline Humic substances-HS & 1 & $10.09^{*}$ & $1.50^{\text {ns }}$ & $0.10^{\text {ns }}$ & $2.96^{\mathrm{ns}}$ & $0.28^{\text {ns }}$ & $2.50^{\text {ns }}$ \\
\hline HS rate & 3 & $6.58^{*}$ & $0.38^{\text {ns }}$ & $0.70^{\text {ns }}$ & $0.63^{\text {ns }}$ & $0.32^{\text {ns }}$ & $1.53^{\text {ns }}$ \\
\hline Liming $\times \mathrm{HS}$ & 1 & $13.93^{* *}$ & $0.45^{\text {ns }}$ & $0.001^{\text {ns }}$ & $0.07^{\text {ns }}$ & $1.74^{\mathrm{ns}}$ & $0.81^{\text {ns }}$ \\
\hline Liming $\times$ HS rate & 3 & $11.48^{* *}$ & $0.73^{\text {ns }}$ & $2.53^{\text {ns }}$ & $2.58^{\text {ns }}$ & $1.21^{\mathrm{ns}}$ & $1.40^{\text {ns }}$ \\
\hline $\mathrm{HS} \times \mathrm{HS}$ rate & 3 & $5.70^{*}$ & $0.02^{\text {ns }}$ & $2.24^{\mathrm{ns}}$ & $3.02^{*}$ & $2.03^{\text {ns }}$ & $1.04^{\mathrm{ns}}$ \\
\hline Liming $\times \mathrm{HS} \times \mathrm{HS}$ rate & 3 & $7.13^{* *}$ & $0.25^{\mathrm{ns}}$ & $2.12^{\text {ns }}$ & $5.06^{*}$ & $0.87^{\text {ns }}$ & $3.76^{*}$ \\
\hline Error & 32 & - & - & - & - & - & - \\
\hline CV & - & 51.48 & 37.62 & 15.49 & 23.88 & 18.33 & 56.56 \\
\hline
\end{tabular}

Liming: application or not of lime; HS: use of humic or fulvic acid; HS rate: application rate of humic substances. ns: not significant; * and **: significant at $5 \%$ and $1 \%$ probability, respectively. Cond: electrical conductivity.

Table 4

Mean values of nutrients in soil samples in the top $(0-20 \mathrm{~cm})$ and bottom $(20-40 \mathrm{~cm})$ layers of columns containing soil with or without pH correction

\begin{tabular}{ccccccc}
\hline \multirow{2}{*}{ Lime } & $\mathrm{P}$ & $\mathrm{K}$ & $\mathrm{Ca}$ & $\mathrm{Mg}$ & $\mathrm{pH}^{*}$ & Cond \\
\cline { 2 - 7 } & & $----\mathrm{mg} \mathrm{kg}^{-1}----$ & - & $\mu \mathrm{cm}^{-1}$ \\
Lack & $0.2 \mathrm{~b}$ & $37.0 \mathrm{a}$ & $0.8 \mathrm{~b}$ & $0.2 \mathrm{~b}$ & $4.5 \mathrm{~b}$ & $42.5 \mathrm{~b}$ \\
Presence & $0.5 \mathrm{a}$ & $40.7 \mathrm{a}$ & $5.2 \mathrm{a}$ & $1.0 \mathrm{a}$ & $7.8 \mathrm{a}$ & $124.8 \mathrm{a}$ \\
& & \multicolumn{7}{c}{$(0-20 \mathrm{~cm})$} \\
Lack & $0.4 \mathrm{a}$ & $48.5 \mathrm{a}$ & $0.9 \mathrm{~b}$ & $0.0 \mathrm{~b}$ & $4.6 \mathrm{~b}$ & $72.0 \mathrm{~b}$ \\
Presence & $0.4 \mathrm{a}$ & $41.4 \mathrm{a}$ & $5.8 \mathrm{a}$ & $0.8 \mathrm{a}$ & $7.3 \mathrm{a}$ & $133.6 \mathrm{a}$
\end{tabular}

${ }^{*} \mathrm{pH}$ in $\mathrm{CaCl}_{2}$. Means followed by the same letter (comparing the correction effect for each type of sample) do not differ among one another according to Tukey's test at $5 \%$ probability. 
In regard to the interaction between liming and humic substances, it was possible to observe that, under alkaline soil conditions (where lime was added), there was no significant difference between the humic and fulvic acid sources as to Ca content, with values of 5.4 and $5.1 \mathrm{mg} \mathrm{kg}^{-1}$, respectively (Figure 1), being liming the greatest Ca source in that soil. However, in soil without lime application, the fulvic acid released more $\mathrm{Ca}$ in soil (1.0 $\left.\mathrm{mg} \mathrm{kg}^{-1}\right)$ when compared with humic acid $\left(0.6 \mathrm{mg} \mathrm{kg}^{-1}\right.$ ) (Figure 1).

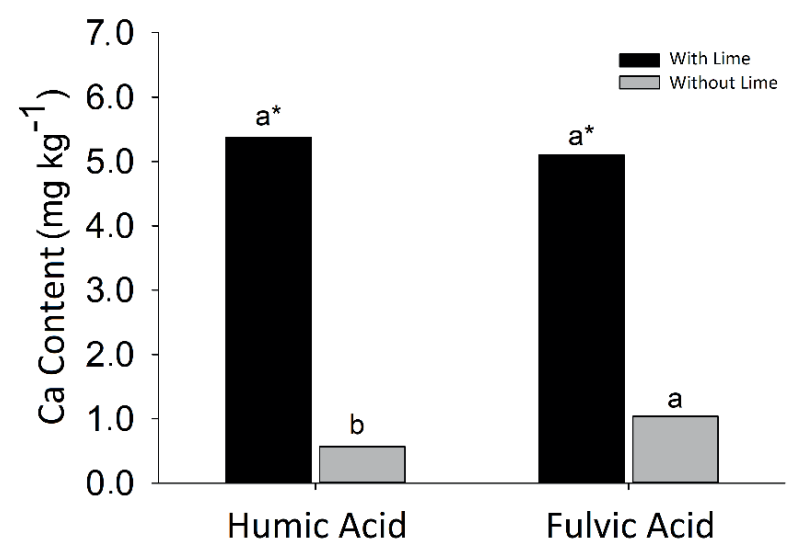

Figure 1. Exchangeable Ca content in 0-20 cm layer of soil-filled column as a function of application of lime and humic substances. Means followed by the same letter, comparing humic substances, for application or not of lime, do not differ from each other, according to Tukey's test at $5 \%$ probability. * indicates significant difference between application or not of lime for the same humic substance.

The solubility of humic substances may explain such effect, since both organic acids are soluble under basic $\mathrm{pH}$ conditions, though, under acidic conditions, the humic acid is insoluble, which causes difficulties for its mineralization and consequent availability of nutrients from its organic matrix (Baldotto \& Baldotto, 2014; Melo et al., 2016).

Another hypothesis is associated with the generation of charges by fulvic acid. According to Yang et al. (2013) and Campitelli, Velasco and Ceppi (2003), one of the most important attributes of fulvic acid is negative charge generation, which mainly results from dissociation of functional groups (phenolic and carboxylic). Furthermore, the fulvic acid, when compared to humic acid, presents greater number of reactive functional groups, due to a lower molecular weight, which enables higher efficiency in interaction with ions, thus favoring the permanence of those ions in soil.

Upon analysis of the interaction among soil correction, humic substances and application rates, it was possible to identify higher $\mathrm{P}$ availability in soil, provided by humic acid after soil $\mathrm{pH}$ correction, with tendency of increment in $\mathrm{P}$ content after application of 120 $\mathrm{L} \mathrm{ha}^{-1}$ in the $0-20 \mathrm{~cm}$ layer (Figure $2 \mathrm{~A}$ ), even with small amount of $P$ in the organic matrix of humic acid $\left(10 \mathrm{mg} \mathrm{kg}^{-1}\right)$. On the other hand, $P$ release by fulvic acid presented opposite effect, showing linear and direct tendency under acidic soil conditions (Figure 2D) and indirect tendency in alkaline soil (Figure $2 \mathrm{~A}, \mathrm{C}$ ), being associated with the fulvic acid solubility under acidic conditions, which promotes 
higher nutrient release and retention in the soil, after irrigations. Similarly, Yang et al. (2013) verified higher $P$ availability with the use of fulvic acid in acid soil. According to the authors, as the application rates of fulvic acid increased, there was substantial increment in microbial population, OM content and CEC, thus optimizing $P$ availability conditions. They concluded that the use of fulvic acid, in combination with a mineral source, is the best option to enhance $\mathrm{P}$ availability and soil physical-chemical conditions.

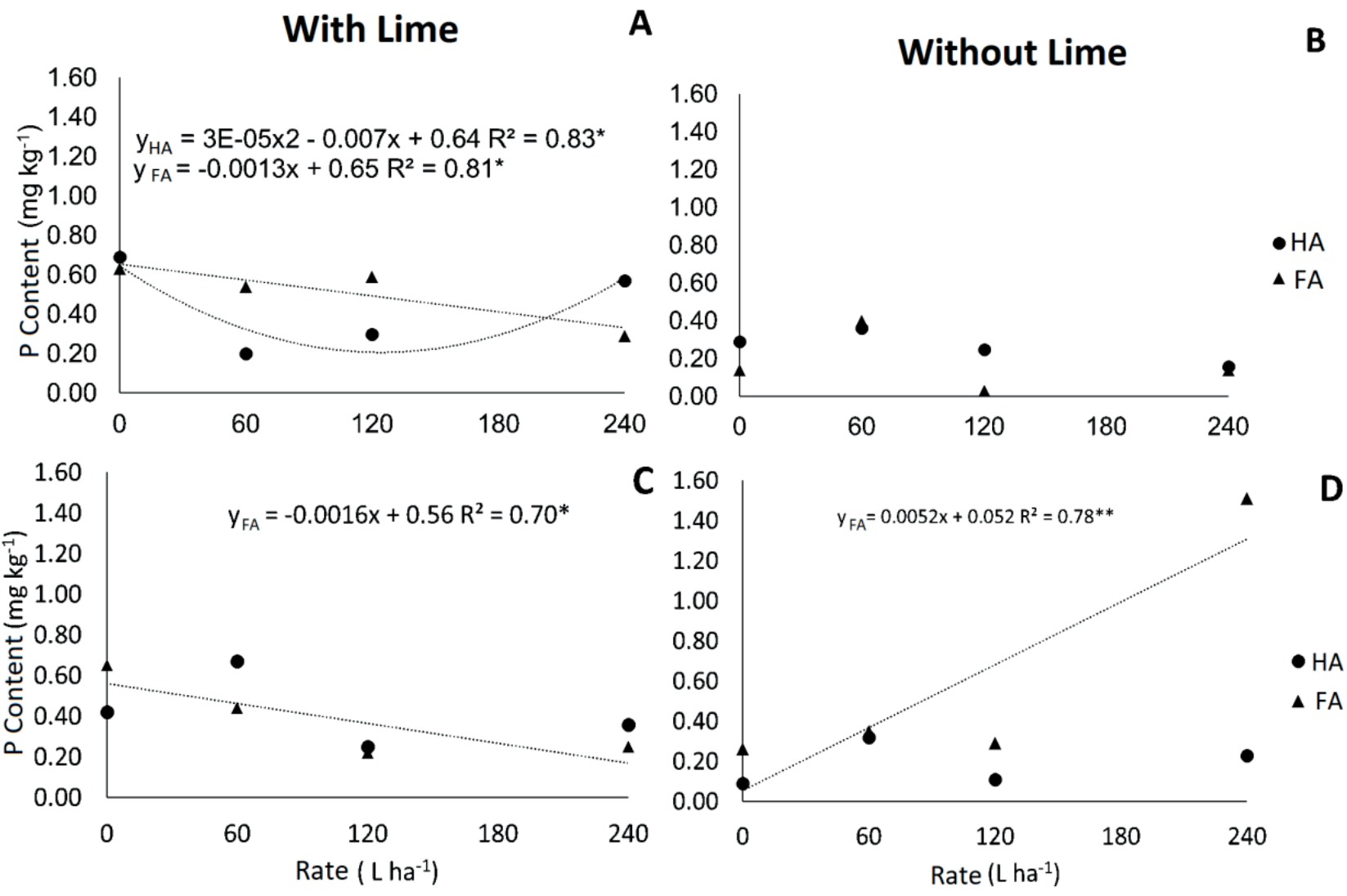

Figure 2. Soil $P$ content, with addition of humic substances, in soil with lime $(A, C)$ and without lime $(B, D)$, in 0-20 cm (A, B) and 20-40 cm (C, D) layers, after 30 days of irrigation. ** and * Significant at $1 \%$ and $5 \%$. 
Global data surveys on humic substances were compiled in review studies by Guo, Liu, \& Wu (2019) and Rose et al. (2014), where the potential of humic substances to reduce soil nutrient leaching was highlighted, since they promote the formation of chelates or metal ion complexes with the ions $\mathrm{Ca}^{2+}$, $\mathrm{Mg}^{2+}, \mathrm{K}^{+}$and $\mathrm{Al}^{3+}$, then influencing the solubility of those elements.

According to Piccolo, Pietramellara, \& Mbagwu (1996), the reason for that is the presence of functional groups in humic substances that quickly react with polyvalent cations on the surface of clay particles, thus forming clay-metal-humus complexes, which would prevent leaching and promote soil nutrient retention. Moreover, it should be pointed out that $P$ is an element that is highly retained in the soil, especially in more weathered ones, such as Oxisols, due to its oxidic and kaolinitic mineralogy (Eghball, Sander, \& Skopp, 1990), turning its leaching and release in soil solution a more difficult process.

Therefore, $\mathrm{P}$ availability is optimized in acid soil, where this element is solubilized and becomes more available in the exchange complex, which justifies the higher $\mathrm{P}$ availability under acidic conditions than in basic conditions in 20-40 cm layer (Figure 2 C, D). Fulvic acid presented greater amount of $P$ in the organic matrix than humic acid, which justifies the more significant $P$ results upon addition of fulvic acid. From the total $P$ in the soil, fulvic acid added $1.4 \mathrm{mg} \mathrm{kg}^{-1}$, considering the highest application rate of $240 \mathrm{~L} \mathrm{ha}^{-1}$.

In regard to $\mathrm{Mg}$ content retained in the $0-20 \mathrm{~cm}$ soil layer, after the irrigation events, the addition of humic acid tends to promote increment of content as from 120 $\mathrm{L} \mathrm{ha}^{-1}$ (Figure 3A). Similarly, Silva and Lana (2015) identified increased $\mathrm{Mg}$ content as a function of higher application rates of humic acid, which represented an increment of $44 \%$ in the $\mathrm{Mg}$ present in the soil, when compared with soil where humic acid was not applied. This is an important result, considering that Cerrado soils usually present Mg deficiency (Souza \& Lobato, 2004) and this effect can be minimized in soils cultivated with the use of liming treatment.

In respect to the evaluation of soil electrical conductivity in the $20-40 \mathrm{~cm}$ layer, it was possible to identify that, under acidic soil conditions, the addition of fulvic acid at increasing rates tends to increase soil electrical conductivity linearly (Figure 3 D). In a similar manner, other authors (Conte et al., 2017; Oliveira, Mattiazzo, Marciano, \& Rossetto, 2002) verified linear increment of soil electrical conductivity with application of biosolids. Nevertheless, electrical conductivity values did not constitute restrictions, such as toxicity in soil caused by an ion or nutritional imbalance. According to Richards (1954), electrical conductivity is considered critical when values exceed $2,000 \mu \mathrm{S} \mathrm{cm}^{-1}$. 


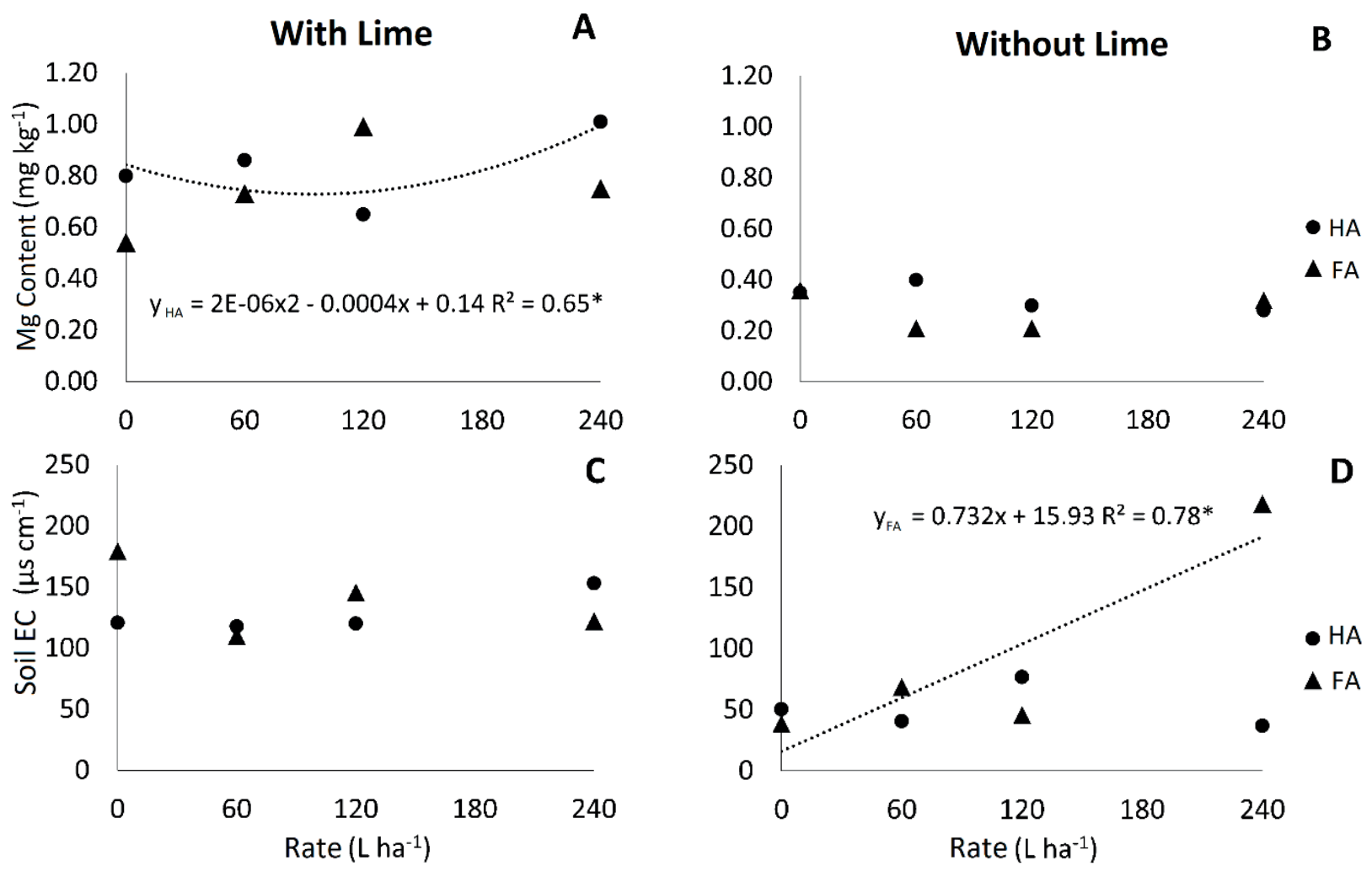

Figure 3. Effect of addition of humic substances to soil with and without lime on $\mathrm{Mg}$ content $(\mathrm{A}, \mathrm{B})$ and electrical conductivity (C, D) of $20-40 \mathrm{~cm}$ soil layer, after 30 days of irrigation. * Significant at $5 \%$.

In alkaline soil (with the presence of lime), the addition of humic substances did not produce significant effect on electrical conductivity (Figure 3C), probably due to $\mathrm{pH}$ balance condition, which promoted higher interaction or complexation among generated charges (Guo et al., 2019).

\section{Conclusions}

Under acidic soil conditions, the use of fulvic acid promoted the release of $40 \%$ more $\mathrm{Ca}$ in the $0-20 \mathrm{~cm}$ layer, when compared to the use of humic acid.

At the application rate of $240 \mathrm{~L} \mathrm{ha}^{-1}$, the use of fulvic acid released $83 \%$ more phosphorus in the $20-40 \mathrm{~cm}$ soil layer.
Under corrected soil conditions, the use of humic acid promoted the release of $20 \%$ more $\mathrm{Mg}$ in the $20-40 \mathrm{~cm}$ soil layer, with the application rate of $240 \mathrm{~L} \mathrm{ha}^{-1}$.

The addition of humic substances to the soil, under acidic or alkaline conditions, did not influence $\mathrm{K}$ concentration in soil.

\section{Acknowledgments}

This work was supported by the University of Rio Verde (Master's degree in Crop Production) and was financed in part by the coordination for the improvement of Higher Education Personnel - Brazil (CAPES) "Finance Code 001" 


\section{References}

Baldotto, M. A., \& Baldotto, L. E. B. (2014). Ácidos húmicos. Revista Ceres, 61(suppl.), 856-881. doi: 10.1590/0034$737 \times 201461000011$

Campitelli, P. A., Velasco, M. I., \& Ceppi, S. B. (2003). Charge development and acidbase characteristics of soil and compost humic acids. Journal Chilean Chemical Society, 48(3), 91-96. doi: 10.4067/S071797072003000300018

Conte, A. M., Marques, R. D., Reis, A. S., \& Viecelli, H. A. (2017). Colunas de lixiviação com solos de texturas arenosa e argilosa e aplicação de biossólidos. Scientia Agraria Paranaensis, 16(3), 302-307. doi: 10.18188/1983-1471/sap.v16n3p302-307

Costa, A. C. C., Nanni, M. R., \& Jeske, E. (1997). Determinação da umidade na camapcidade de campo e ponto de murcha permanente por diferentes metodologias. Revista Unimar, 19(3), 827844.

Eghball, B., Sander, D. H., \& Skopp, J. (1990). Diffusion, adsorption and predicated longevity of banded phosphorus fertilizer in three soils. Soil Science of American Jounal, 54(4), 1161-1165. doi: 10.2136/ sssaj1990.03615995005400040041x

Empresa Brasileira de Pesquisa Agropecuária (2009). Manual de análise químicas de solos, plantas e fertilizantes. Brasília: EMBRAPA Informação Tecnológica.

Empresa Brasileira de Pesquisa Agropecuária (2018). Sistema brasileiro de classificação de solos. Brasília: EMBRAPA Informação Tecnológica.
Ernani, P. R. (2008). Química do solo e disponibilidade de nutrientes. Lages: UDESC.

Ferreira, D. F. (2019). SISVAR: a computer analysis system to fixed effects split plot type designs. Revista Brasileira de Biometria, 37(4), 529-535. doi: 10.28951/ rbb.v37i4.450

Guo, X. X., Liu, H. T., \& Wu, S. B. (2019). Humic substances developed during organic waste composting: form Zandoná action mechanisms, structural properties and agronomic functions. Science of the Total Environment, 662, 501-510. doi: 10.1016/j. scitotenv.2019.01.137

Karčauskienè, D., Repšienè, R., Ambrazaitienè, D., Mockevičienè, I., Šiaudinis, G., \& Skuodienè, R. (2019). A complex assessment of mineral fertilizers with humic substances in an agroecosystem of acid soil. Zemdirbyste-Agriculture, 106(4), 307-314. doi: 10.13080/z-a.2019.106.039

Melo, B. A. G., Motta, F. L., \& Santana, M. H. A. (2016). Humic acids: structural properties and multiple functionalities for novel technological developments. Material Sciende and Engineering C, 62, 967-974. doi: 10.1016/j.msec.2015.12.001

Oliveira, F. C., Mattiazzo, E., Marciano, C. R., \& Rossetto, R. (2002). Efeitos de aplicações sucessivas de lodo de esgoto em um latossolo amarelo distrófico cultivado com cana-de-açúcar: carbono orgânico, condutividade elétrica, pH e CTC. Revista Brasileira de Ciência do Solo, 26(2), 505519. doi: 10.1590/S0100-06832002000 200025 
Piccolo, A., Pietramellara, G., \& Mbagwu, J. S. C. (1996). Effect of coal derived humic substances on water retention and structural stability of Mediterranean soils. Soil and Use Managment, 12(4), 209-213. doi: 10.1111/j.1475-2743.1996.tb00545.x

Richards, L. A. (1954). Diagnosis improvements of saline and alkaline soils. Washington, DC: USDA.

Robson, A. D., \& Abbott, L. K. (1989). The effect of soil acidity on microbiol activity in soils. In A. D. Robson (Ed.), Soil acidity and plant growth (pp. 167-203). Sydney, NSW: Academic Press.

Rose, M. T., Patti, A. F., Little, K. R., Brown, A. L., Jackson, W. R., \& Cavagnaro, T. R. (2014). A meta-analysis and review of plant-growth response to humic substances: practical implications for agriculture. Advances in Agronomy, 124, 37-89. doi: 10.1016/B978 -0-12-800138-7.00002-4
Schnitzer, M., \& Khan, S. U. (1972). Humic substances in the environment. New York: Marcel Dekker.

Silva, A. A., \& Lana, R. M. Q. (2015). Incubação do verdete com diferentes fontes de ácidos para disponibilização de potássio, cálcio, magnésio do solo. Holos, 5, 73-83. doi: 10.15628/holos.2015.3210

Souza, D. M. G., \& Lobato, E. (2004). Cerrado: correção do solo e adubação. Brasília: EMBRAPA Informação Tecnológica.

Yang, S., Zhang, Z., Cong, L., Wang, X., \& Shi, S. (2013). Effect of fulvic acid on the phosphorus availability in acid soil. Journal of Soil Science and Plant Nutrition, 13(3), 526-533. doi: 10.4067/ S071 8-95162013005000041

Zandoná, R. R., Beutler, A. N., Burg, G. M., Barreto, C. F., \& Schmidt, M. R. (2015). Gesso e calcário aumentam a produtividade e amenizam o efeito do déficit hídrico em milho e soja. Pesquisa Agropecuária Tropical, 45(2), 128-137. 